\title{
Eco Drainage System for Surface Runoff Reduction in Indonesia
}

\author{
Kusumastuti, C..$^{*}$, Chandra, H.P. ${ }^{1}$, Wibisono, K. ${ }^{1}$, and Hartono, A.C. ${ }^{1}$
}

\begin{abstract}
Sustainable urban drainage systems (SUDS) or eco-drainage system has been implemented in developed countries. The aims of the construction of the system are; to minimize surface runoff by capturing and temporarily retain it, to improve the quality of surface runoff, to infiltrate stormwater, to increase evapotranspiration, and enhance landscape aesthetic value. Learning from the success of the implementation of SUDS in developed countries, the paper presents a model of eco-drainage system for residential area in Indonesia, which consists of rainwater harvesting system (RWHS) and retention ponds. A simulation of stormwater and surface runoff utilization is also presented. At $14,602.26 \mathrm{~m}^{2}$ bare land in Mojokerto Regency, which is transformed into residential area, the model of eco-drainage system could reduce surface runoff volume almost by $70 \%$. It is recommended to adjust the dimension of rainwater storage tank and retention ponds in order to reduce more surface runoff volume.
\end{abstract}

Keywords: Eco-drainage system; rainwater harvesting; residential area; surface runoff; stormwater.

\section{Introduction}

The impact of land use change on hydrological variables has been discussed since a few decades ago. Leopold [1] mentioned that land use change causes the change of surface runoff characteristics and its total volume, change of the quality of water, and hydrologic amenities. To be specific, the increasing of imperviousness will cause the increasing of flood discharge. To cope with that situation, most cities in the world have constructed the conventional drainage system. The system aims to remove excess water as fast as possible. However, this system causes several negative impacts [2], such as; increasing downstream flood discharge, reducing the amount of stormwater infiltrates to the ground which further causes the reduction of groundwater level, and degradation of strowmwater quality due to inflow from contaminated-surface runoff, i.e. oil, organic matter, and heavy metal.

In developed countries, such as some European countries, the United State (U.S.), and Australia, environmental health has been an additional concern to design modern urban drainage system. There are various terminology used in different countries though the purpose of the design is relatively the same. In Europe, it is called Sustainable Urban Drainage System (SUDS) [3].

${ }^{1}$ Department of Civil Engineering, Faculty of Civil Engineering and Planning, Petra Christian University, J. Siwalankerto 121-131, Surabaya 60236, INDONESIA

*Corresponding author; email: cilcia.k@petra.ac.id

Note: Discussion is expected before June, $1^{\text {st }} 2019$, and will be published in the "Civil Engineering Dimension", volume 21, number 2, September 2019 .

Received 26 February 2019 revised 04 March 2019; accepted 17 March 2019
In Australia, the term Water Sensitive Urban Design (WSUD) is used while in the US, Low Impact Development (LID) [4] is a more familiar term. In the next section, the term of eco-drainage system will be used since the term is commonly used in Indonesia as the study area of this paper.

Basically, the main principles of eco-drainage system are to minimize surface runoff by capturing and temporarily retain it (e.g. rainwater storage, detention/ retention ponds, and wetlands) [2-5], to improve the quality of surface runoff (e.g. detention/retention ponds and wetlands) [2], to infiltrate stormwater (e.g. infiltration trenches, permeable surface, biofiltration swales) [3,4], to increase evapotranspiration (e.g. rain garden and green roof) [4], and enhance landscape aesthetic value [2] (e.g. ponds and wetlands).

\section{Eco-drainage System Practices}

The implementation of eco-drainage system has various backgrounds in different countries. In mega cities such as Chicago, London, New York, and Tokyo, eco-drainage system has been implemented to reduce surface runoff and to prevent the occurrence of urban flooding [6]. Different measures have been used such as, increasing urban forest and rooftop garden in Chicago, flood storage in the riverbanks parks in London, a combination of bioretention and biofiltration, green area to absorb water, and installlation of rainwater harvesting system in New York, and the use of water-retaining pavement as well as expansion of urban forest in Tokyo.

Indonesia is a developing country in Southeast Asia. The number of population in Indonesia continuously grows. It reaches more than 237 million in 2010 
which is double of the number in 1971. This occurs along with the expansion of residential areas in many cities in Indonesia. The expansion of residential area, specifically in Java Island, means changing bare land, forest, or farm area into residential area. It transforms permeable surface into impermeable surface which further will effect to the increasing of surface runoff volume. A study by Kusumastuti et al. [7] revealed an increasing peak flood discharge in Probolinggo Regency, East Jawa, Indonesia, from 2010 to 2015 by $1.75 \%$ due to land use change. Dense forest, local plantations, and bare land were transformed into chemical industrial area and residential area.

Eco-drainage system has been stated in the appendix of Ministerial Regulation No. 12/PRT/M/2014 [8] as an effort to manage the excess water due to rainfall by using various methods such as capturing rainwater, storing or directly using it, delivering excess rainfall into retention pond, or infiltrating it into groundwater. Several study of implementation of eco-drainage system in residential area in Indonesia shows positive result on surface runoff reduction in different cities in Indonesia. Ardiyana, et al. [9] observed the reduction of surface runoff by $14.49 \%$ 92.26\% in a real estate in Malang City, East Jawa, Indonesia, by constructing recharge wells, bio-retention cells, and permeable pavement. Previous study by Aflakhi, et al. [10] also had similar result when the reduction of surface runoff by $83.5 \%$ could be achieved when recharge wells and bio-retentions cells in real estate in Semarang City, Central Jawa, Indonesia, are constructed.

The next section of the paper provides a model of ecodrainage system in a city in East Jawa, Indonesia. The model is expected to provide an effort that could be done to minimize surface runoff volume as well as promote aesthetic value of landscape in a residential area. It also provides the possibility of rainwater usage through rainwater harvesting system at household scale.

\section{Model of Eco-drainage System for Residential Area in Indonesia}

A bare land of $14,602.26 \mathrm{~m}^{2}$ in Mojokerto Municipality, East Jawa, Indonesia, is planned to be developed into a real estate. This development may cause the increasing of runoff volume. Among several methods to manage excess rainfall stated in the appendix of Ministerial Regulation No. 12/PRT/M/ 2014 [8], the methods chosen as a part of the model consists of capturing rainwater through rainwater harvesting system (RWHS) and constructing retention ponds. The utilization of rainwater and water in the retention ponds will also be demonstrated in this paper. On the other hand, the other method, i.e. infiltrating rainwater is excluded in the model since soil characteristics vary in different regions in Indonesia. Therefore, the methods may not be suitable for every city. The combination of RWHS and retention ponds is expected to be a model which can be implemented in other cities in Indonesia.

\section{Study Area}

Mojokerto Municipality is located at $07^{\circ} 33$ ' South latitude and $112^{\circ} 28^{\prime}$ East longitude, in the centre of Mojokerto Regency, East Jawa Province, Indonesia. It has a total land area of $16.47 \mathrm{~km}^{2}$, which in 2016 , 702.15 hectare of it, is used as residential area [11]. The normal annual precipitation in Mojokerto Regency is above $2000 \mathrm{~mm}$. The temperature varies from $22.3^{\circ}-33.8^{\circ} \mathrm{C}$. Data of daily rainfall from $2000-$ 2015 was collected and analyzed to determine the capacity of each component of the proposed ecodrainage system in this paper.

\section{Rainfall Characteristics}

Data of average daily rainfall was analyzed to determine the capacity of rainwater storage tank, water balance in the retention pond, and the capacity of the retention pond. The result of rainfall data analysis shows that Mojokerto Municipality received maximum daily rainfall varies from $38.94-$ $77.50 \mathrm{~mm}$ and average daily rainfall from 0.77 $15.62 \mathrm{~mm}$.

Other data to be used in the analysis are data of monthly average number of rain and dry days, and average temperature. Those data were the main data to observe monthly water balance in the rainwater storage tank and in the retention pond. The complete data is presented in Table 1.

Table 1. Monthly Average Daily Rainfall, Average Number of Rain and Dry Days, and Average Temperature

\begin{tabular}{lcccc}
\hline Month & $\begin{array}{c}\text { Average } \\
\text { daily } \\
\text { rainfall } \\
(\mathrm{mm})\end{array}$ & $\begin{array}{c}\text { Average } \\
\text { number of } \\
\text { rain days }\end{array}$ & $\begin{array}{c}\text { Average } \\
\text { number of } \\
\text { dry days }\end{array}$ & $\begin{array}{c}\text { Average } \\
\text { temperature } \\
*\left({ }^{\circ} \mathrm{C}\right)\end{array}$ \\
\hline Jan & 15.62 & 25 & 6 & 26.5 \\
Feb & 14.83 & 24 & 4 & 26.4 \\
March & 15.27 & 24 & 7 & 26.6 \\
April & 10.48 & 19 & 11 & 26.7 \\
May & 5.88 & 15 & 16 & 26.6 \\
June & 2.19 & 6 & 24 & 26.1 \\
July & 0.77 & 3 & 28 & 25.7 \\
Aug & 0.43 & 2 & 29 & 26.2 \\
Sept & 0.89 & 2 & 28 & 26.8 \\
Oct & 3.10 & 7 & 24 & 27.4 \\
Nov & 6.85 & 14 & 16 & 27.4 \\
Dec & 12.83 & 23 & 8 & 26.9 \\
\hline
\end{tabular}

*Source: http://id.climate-ata.org/location/977152/[12] 


\section{Methods}

Water balance is the main principle to determine the capacity of rainwater storage tank and retention pond of eco-drainage system in this paper. It includes the volume of inflow, outflow, and the difference between inflow and outflow ( $\Delta$ storage) both in the rainwater storage tank and the retention pond.

Inflow to the rainwater storage tank was obtained from the multiplication of the depth of monthly average daily rainfall and the catchment area (roof surface). While the outflow was designed differently every month in the year based on the availability of rainwater and standard of water requirement per person per day by World Health Organization [13] i.e. sanitation and waste disposal (70 liter/day), personal washing (30 litre/day), and washing clothes (40 liter/day); and for a household per day i.e. gardening (90 liter/day) and cleaning home (50 liter/ day).

The retention pond has several sources water as an inflow, i.e. from surface runoff of the whole area of the real estate except from the roof surface, which is captured and stored in the rainwater tank in each house, and the rain which falls on the retention pond. The peak runoff flows to the retention pond is estimated using the Rational Formula [14] in Equation (1).

$Q=C I A$ where:

$Q$ = peak discharge (cfs)

$C=$ runoff coefficient

$I=$ rainfall intensity (in/hour)

$A=$ catchment area (acres)

It is then used to estimate the daily runoff volume due to 4-hour rainfall. After retention pond is filled of water from surface runoff, the water is planned to be used for watering public garden in the real estate. This is considered as the outflow of the retention pond. The detail of monthly water use of the retention pond is presented in Table 4. Water balance in the retention pond also considers the loss of water due to evapotranspiration. It is estimated using Thornthwaite method [15] in Equation (2).

$$
E T_{\text {month }}=1.62\left(\frac{10 T m}{I}\right)^{a}
$$

for:

$$
\begin{aligned}
& \mathrm{a}=675 \times 10^{-9} \mathrm{I}^{3}-771 \times 10^{-7} \mathrm{I}^{2}+179 \times 10^{-4} \mathrm{I}+ \\
& 179 \times 10^{-4} \mathrm{I}+492 \times 10^{3} \\
& I=\sum_{n=1}^{12}\left(\frac{T m}{5}\right)^{1.514}
\end{aligned}
$$

where:

ETmonth = monthly potential evapotranspiration (cm)

$\mathrm{Tm} \quad=$ average monthly temperature $\left({ }^{\circ} \mathrm{C}\right)$

I $\quad=$ annual heat index

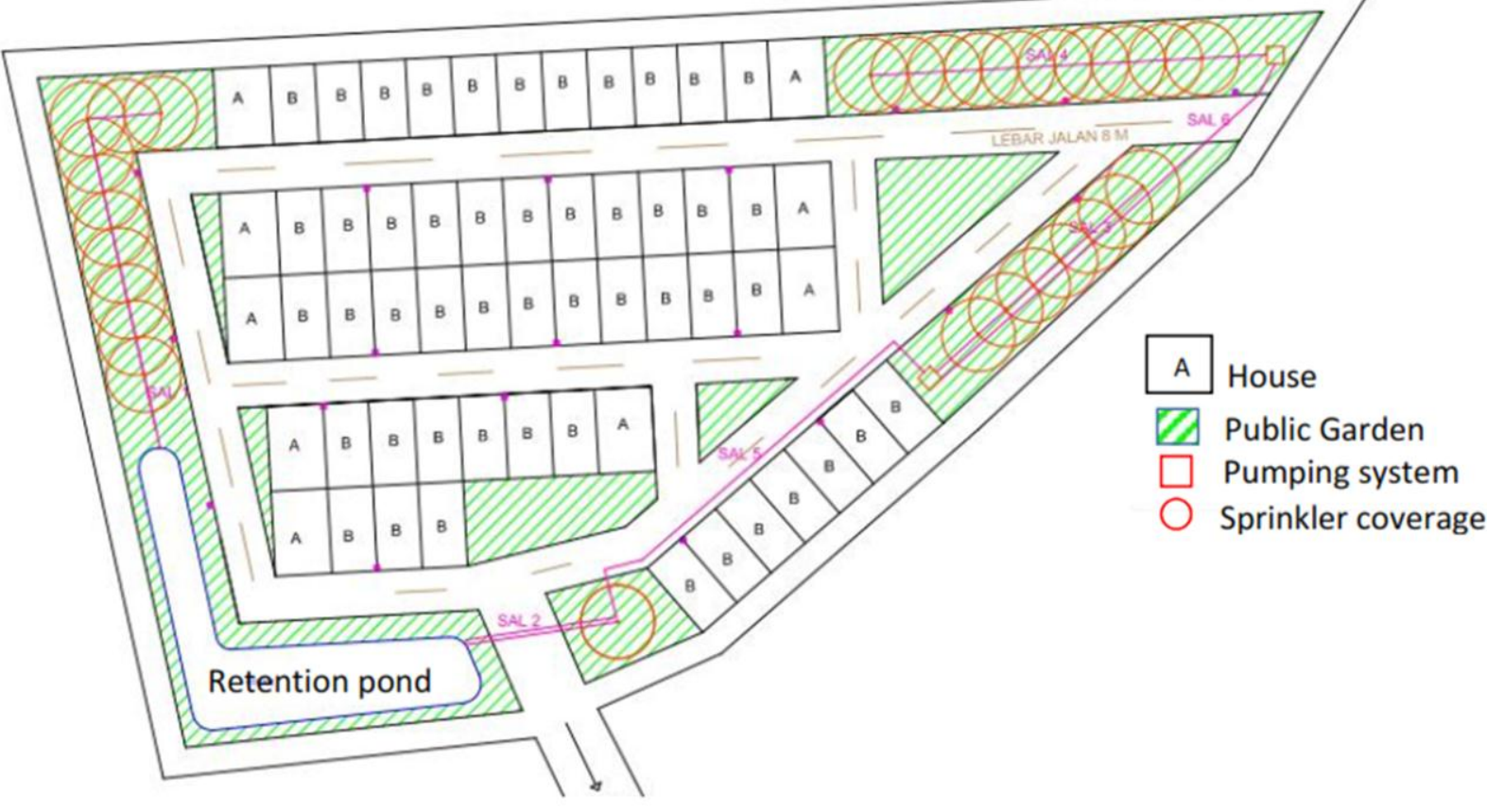

Exit

Figure 1. Lay Out of the Real Estate with Eco-drainage System (not to scale) 


\section{Model of Residential Area in Indonesia for Eco-Drainage System Development}

According to Law of Indonesia Number 26 article 29 verses (2) [16], the proportion of green area in a city is at least $30 \%$ of a total land area. Therefore, a design of real estate development after the year of 2007 must consider the contribution to the total open space in the city. The design of the real estate discussed in this paper consists of $4219.9 \mathrm{~m}^{2}(28.89 \%)$ of houses (roof surface) and $10389.36 \mathrm{~m}^{2}(71.11 \%)$ of public and private open space. Therefore, the real estate has been designed following the legal regulation in Indonesia. The design of land use of the real estate produces 0.3154 of runoff coefficient (C). The layout of the real estate is shown in Figure 1.

Runoff coefficient is an important factor contributing to the peak flood discharge as can be seen in Equation (1). Another variable contributing the peak flood discharge using the Rational Formula is rainfall intensity. Data of rainfall intensity in this paper is estimated from daily rainfall depth which is transformed into rainfall intensity using Mononobe Formula. However, the detail of the calculation is not presented here. It is taken from a research by Wibisono and Hartono [17] and presented in Table 2. After all components have been determined, the estimated volume of runoff due to 4-hour rainfall in the study area starting in November is presented in Table 2.

\section{Rainwater Harvesting System}

Rainwater harvesting system (RWHS) for domestic use at household scale consists of three components i.e. catchment area (roof surface), delivery system (gutters and drain pipes), and storage tank [18]. The capacity of the storage tank is determined based on the different between inflow and outflow. The inflow is mainly from rainfall while the outflow is from domestic water need in each house. It is estimated based on the need of water of 4 (four) members of a household. Therefore, the daily water need, such as for sanitation and waste disposal, personal washing, and washing clothes of each household is multiplied by 4 (four).

The simulation of the use of rainwater in the storage tank starts in November. That month is the second month of rainy season in the study area. It is considered that at that time, rainwater has filled the storage and can meet the water need. The monthly runoff volume is estimated based on monthly average number of rain days as presented in Table 1.

Using the data of average daily rainfall data and average number of rain days which are presented in Table 1 and $50.2 \mathrm{~m}^{2}$ of roof surface (the catchment area of the RWHS is shown in Figure 2), the monthly inflow to the storage tank is presented in Table 3. Due to the variation of monthly rainwater volume in a year, the system is designed to work at 4 (four) scenarios of water use. The first scenario, the water as much as 50 litre/day is used for cleaning home. The second scenario, the water as much as 450 litre/day is used for sanitation \& waste disposal and personal washing for 4 (four) members of the household and cleaning home. The third scenario, the water as much as 610 liter/day is used for sanitation \& waste disposal, washing clothes, and personal washing for 4 (four) members of the household as well as cleaning home. The fourth scenario, water as much as 90 liter/day is used for gardening. Those four scenarios of water use are applied in different month during the year. These scenarios are determined based on the quantity of rainwater. Further investigation of water quality may be needed.

Table 2. Volume of Runoff in the Study Area [17]

\begin{tabular}{lcc}
\hline Month & $\begin{array}{c}\text { Rainfall Intensity } \\
(\mathrm{mm} / \text { hour })\end{array}$ & $\begin{array}{c}\text { Volume of runoff } \\
\left(\mathrm{m}^{3} / \text { month }\right)\end{array}$ \\
\hline Nov & 8.29 & 2139.79 \\
Dec & 15.52 & 6581.25 \\
Jan & 18.91 & 8716.07 \\
Feb & 17.94 & 7938.21 \\
March & 18.48 & 8177.16 \\
April & 12.68 & 4441.83 \\
May & 7.11 & 1966.30 \\
June & 2.49 & 275.45 \\
July & 0.94 & 51.99 \\
Aug & 0.52 & 19.17 \\
Sept & 1.07 & 39.46 \\
Oct & 3.76 & 485.26 \\
\hline
\end{tabular}

Based on the estimation of inflow and outflow in the RWHS and accumulation of storage in a year, it is determined that two storage tanks of 2200 litre capacity should be installed in a house. Therefore, it has a total of 4400 litre storage capacity. The water balance of the RWHS is presented in Table 3. It shows that in January, February, and March 4400 litre of storage tank does not adequate to accommodate the inflow from rainfall. It causes overflow, which in the end contributes to the retention pond.

\section{Retention Pond}

A rectangular retention pond in the study area is determined as large as $800 \mathrm{~m}^{2}$ and $1.5 \mathrm{~m}$ deep. Therefore, it has a capacity of $1200 \mathrm{~m}^{3}$. The water is planned to be used to water the public garden in the real estate using a sprinkler system. Detail calculation of the sprinkler system is not discussed in this paper. The operational system of the sprinkler system is based on the number of dry days in the study area. It is presented in Table 4. In the rain days, it is considered that the garden does not need any additional water from the sprinkler system.

The catchment area of surface runoff calculation is the whole area of the real estate without the roof surface since the rain falls on to it is captured and stored in the rainwater tank in each house. The detail of inflow-outflow- $\Delta$ storage in the retention pond is presented in Table 4 . 


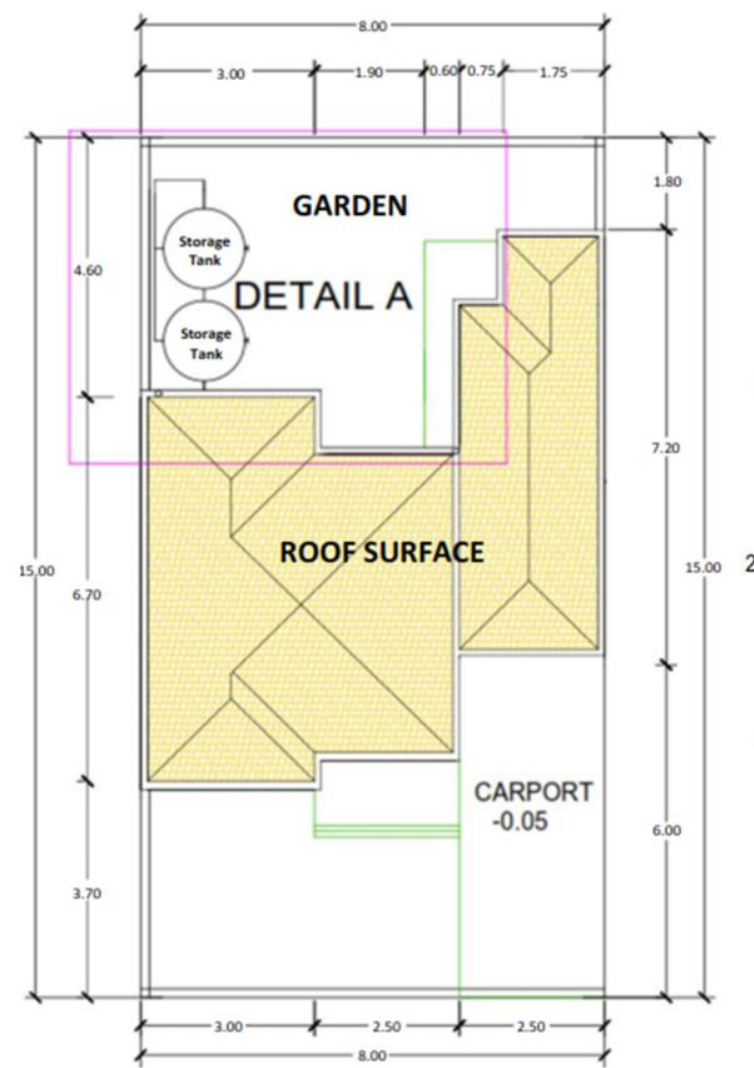

(a)

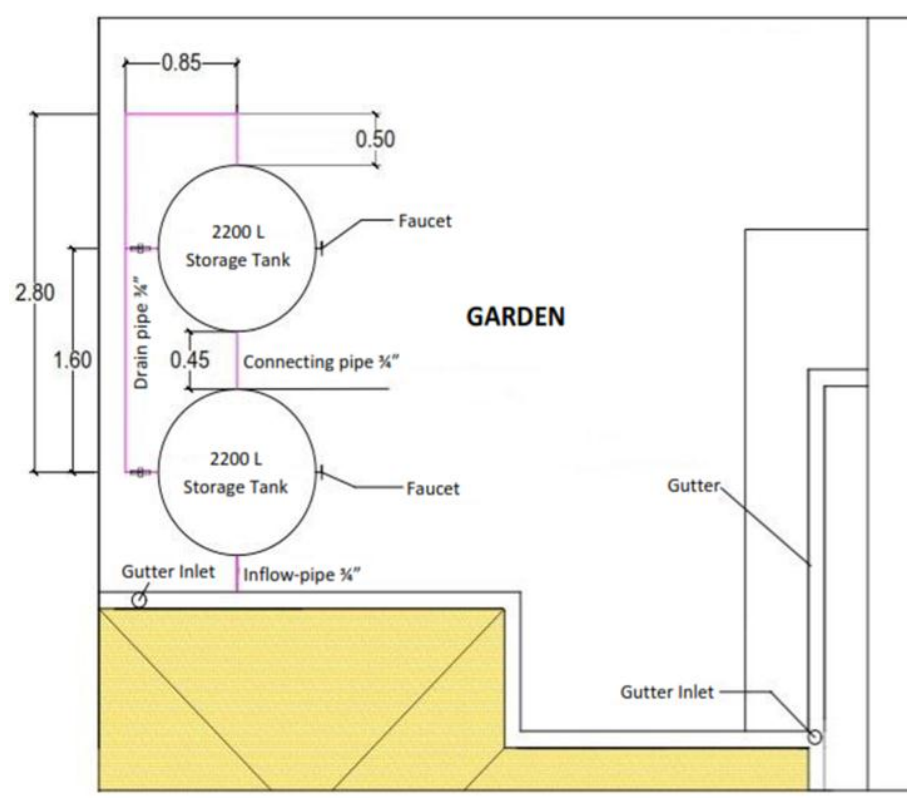

(b)

Figure 2. (a) Catchment Area of RWHS; (b) Detail A of RWHS, in Metre (not to scale)

Table 3. Inflow, Outflow, $\Delta$ storage, and Overflow of Rainwater Storage Tank

\begin{tabular}{|c|c|c|c|c|c|c|c|c|}
\hline \multirow{2}{*}{ Month } & \multicolumn{2}{|c|}{ Inflow, $\mathrm{Q}_{\text {in }}$} & \multirow{2}{*}{$\begin{array}{c}\text { Acc. Qin } \\
\text { (ltr/month) }\end{array}$} & \multicolumn{2}{|c|}{ Outflow, Qout } & \multirow{2}{*}{$\begin{array}{l}\text { Acc. Qout } \\
\text { (ltr/month) }\end{array}$} & \multirow{2}{*}{$\begin{array}{l}\Delta \text { storage } \\
\text { (ltr/month) }\end{array}$} & \multirow{2}{*}{$\begin{array}{l}\text { Overflow } \\
\text { (ltr/month) }\end{array}$} \\
\hline & (ltr/day) & (ltr/month) & & (ltr/day) & (ltr/month) & & & \\
\hline Nov & 343.87 & 4814.18 & 4814.18 & $50^{(1)}$ & 1500 & 1500 & 3314.18 & - \\
\hline Dec & 644.07 & 14813.61 & 19267.79 & $450^{(2)}$ & 13950 & 15450 & 4177.79 & - \\
\hline Jan & 784.12 & 19603.00 & 39230.79 & $610^{(3)}$ & 18910 & 34360 & 4870.79 & 470.79 \\
\hline Feb & 744.47 & 17867.28 & 57098.07 & $610^{(3)}$ & 17080 & 51440 & 5658.07 & 1258.07 \\
\hline March & 766.55 & 18397.2 & 75495.27 & $610^{(3)}$ & 18910 & 70350 & 5145.27 & 745.27 \\
\hline April & 526.10 & 9995.9 & 85491.17 & $450^{(2)}$ & 13500 & 83850 & 1641.17 & - \\
\hline May & 295.18 & 4427.7 & 89918.87 & $90^{(4)}$ & 2790 & 86640 & 3278.87 & - \\
\hline June & 109.94 & 659.64 & 90578.51 & $90^{(4)}$ & 2700 & 89340 & 1238.51 & - \\
\hline July & 38.65 & 115.95 & 90694.46 & $90^{(4)}$ & 900 & 90240 & 454.46 & - \\
\hline Aug & 21.59 & 43.18 & 90737.64 & 0 & 0 & 90240 & 497.64 & - \\
\hline Sept & 44.68 & 89.36 & 90827.00 & 0 & 0 & 90240 & 587.00 & - \\
\hline Oct & 155.52 & 1088.64 & 91915.64 & $50^{(1)}$ & 1550 & 91790 & 125.64 & - \\
\hline
\end{tabular}

Note: ${ }^{(1)}$ cleaning home; ${ }^{(2)}$ sanitation and waste disposal + personal washing + cleaning home; ${ }^{(3)}$ sanitation and waste disposal + personal washing + cleaning home + washing clothes; ${ }^{(4)}$ gardening

Table 4. Monthly Water Balance in the Retention Pond

\begin{tabular}{|c|c|c|c|c|c|c|c|c|}
\hline \multirow[b]{2}{*}{ Month } & \multicolumn{3}{|c|}{ Inflow } & \multicolumn{3}{|c|}{ Outflow } & \multirow[b]{2}{*}{$\begin{array}{l}\Delta \text { Storage } \\
\text { (m³/month) }\end{array}$} & \multirow[b]{2}{*}{$\begin{array}{l}\text { Overflow } \\
\text { (m³/month) }\end{array}$} \\
\hline & $\begin{array}{l}\text { Rainfall* } \\
\text { (m³/day) }\end{array}$ & $\begin{array}{l}\text { Surface runoff } \\
\left(\mathrm{m}^{3} / \text { day }\right)\end{array}$ & $\begin{array}{c}\text { Total } \\
\text { (m³/month) }\end{array}$ & $\begin{array}{c}\text { Evapotransp. } \\
\text { (m³/day) }\end{array}$ & $\begin{array}{l}\text { Watering } \\
\text { (m³/day) }\end{array}$ & $\begin{array}{c}\text { Total } \\
\left(\mathrm{m}^{3} / \mathrm{month}\right)\end{array}$ & & \\
\hline Nov & 5.48 & 152.67 & 1481.93 & 4.23 & 34.27 & 675.11 & - & - \\
\hline Dec & 10.26 & 285.98 & 4557.91 & 4.03 & 34.27 & 395.10 & 4162.81 & 2962.81 \\
\hline Jan & 12.50 & 228.96 & 6036.38 & 3.84 & 34.27 & 320.69 & 5715.69 & 4515.69 \\
\hline Feb & 11.86 & 217.21 & 5497.70 & 3.39 & 34.27 & 238.84 & 5258.86 & 4058.86 \\
\hline March & 12.22 & 223.75 & 5663.25 & 3.80 & 34.27 & 353.97 & 5309.28 & 4109.28 \\
\hline April & 8.38 & 153.52 & 3076.19 & 3.68 & 34.27 & 487.36 & 2588.83 & 1388.83 \\
\hline May & 4.70 & 86.09 & 1361.78 & 3.70 & 34.27 & 659.36 & 702.42 & - \\
\hline June & 1.65 & 30.15 & 190.79 & 3.32 & 34.27 & 922.04 & - & - \\
\hline July & 0.62 & 11.38 & 36.00 & 3.22 & 34.27 & 1056.21 & - & - \\
\hline Aug & 0.35 & 6.30 & 13.29 & 3.52 & 34.27 & 1099.38 & - & - \\
\hline Sept & 0.71 & 12.96 & 27.33 & 3.75 & 34.27 & 1071.99 & - & - \\
\hline Oct & 2.48 & 45.52 & 336.03 & 4.29 & 34.27 & 951.24 & - & - \\
\hline
\end{tabular}

Note: *rain falls on the retention pond, "the catchment area excluding the roof surface 
Table 5. Reduction of Runoff Volume in the Study Area

\begin{tabular}{|c|c|c|c|c|c|}
\hline \multirow[t]{2}{*}{ Month } & \multirow{2}{*}{$\begin{array}{l}\text { Surface runoff without eco- } \\
\text { drainage system, } \mathrm{Q}_{1} \\
\left.\text { ( } \mathrm{m}^{3} / \mathrm{month}\right)\end{array}$} & \multirow{2}{*}{$\begin{array}{l}\text { Surface runoff with eco- } \\
\text { drainage system, } \mathrm{Q}_{2} \\
\text { (m³/month) }\end{array}$} & \multirow[t]{2}{*}{$\begin{array}{c}\text { Contribution from } \\
\text { RWHS, } Q_{3}\left(\mathrm{~m}^{3} / \text { month) }\right.\end{array}$} & \multicolumn{2}{|c|}{$\begin{array}{c}\text { Runoff volume reduction, } \\
\Delta \Delta Q=Q_{1}-Q_{2}+Q_{3}\end{array}$} \\
\hline & & & & (m³/month) & $\%$ \\
\hline Nov & 2139.79 & 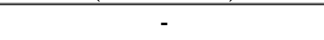 & - & 2139.79 & 100.00 \\
\hline Dec & 6581.25 & 2962.81 & - & 3618.44 & 54.98 \\
\hline Jan & 8716.07 & 4515.69 & 0.47 & 4200.85 & 48.20 \\
\hline Feb & 7938.21 & 4058.86 & 1.26 & 3880.62 & 48.89 \\
\hline March & 8177.16 & 4109.28 & 0.75 & 4068.62 & 49.76 \\
\hline April & 4441.83 & 1388.83 & - & 3053.00 & 68.73 \\
\hline May & 1966.30 & - & - & 1966.30 & 100.00 \\
\hline June & 275.45 & - & - & 275.45 & 100.00 \\
\hline July & 51.99 & - & - & 51.99 & 100.00 \\
\hline Aug & 19.17 & - & - & 19.17 & 100.00 \\
\hline Sept & 39.46 & - & - & 39.46 & 100.00 \\
\hline Oct & 485.26 & - & - & 485.26 & 100.00 \\
\hline
\end{tabular}

\section{Reduction of Runoff Volume}

RWHS and the retention pond are designed to minimize the runoff volume. The reduction of runoff volume due to the construction of the eco-drainage system is presented in Table 5.

The percentage of runoff volume reduction which is presented in Table 5 varies from month to month in a year. In the peak of rainy season, January, the highest overflow is detected.

\section{Conclusions}

Eco-drainage system has been established for surface runoff reduction as well as environment health around the world. In Indonesia, the methods to achieve proper eco-drainage system have been stated in ministerial regulation. Combination of several methods has been implemented in several cities in Indonesia and resulting in positive impact on surface runoff reduction due to the expansion of residential area. The model of eco-drainage system in a residential area in Indonesia which is designed following the legal regulation of Indonesian to have more than $30 \%$ of open space shows possible reduction of surface runoff volume almost by $70 \%$. The combination of RWHS and retention ponds as well as the utilization of rainwater demonstrated in this paper, is expected could be implemented in different areas in Indonesia. In addition, the remaining 30\% of excess rainfall could be minimized further by adjusting the size of rainwater storage and the retention ponds or by introducing infiltration trench in particular regions in Indonesia.

\section{References}

1. Leopold, L.B., Hydrology for Urban Land Planning- A Guidebook on the Hydrologic Effects of Urban Land Use, Geological Survey Circular 554, U.S. Geological Survey, Washington, DC, USA, 1968.

2. Environment Agency, Sustainable Drainage Systems (SUDS)- A Guide for Developers, Environment Agency, UK, 2003.
3. Zhou, Q., A Review of Sustainable Urban Drainage Systems Considering the Climate Change and Urbanization Impacts, Water, 6, 2014, pp. 976-992,

4. Roy, A.H., Wenger, S.J., Fletcher, T.D., Walsh, C.J., Ladson, A.R., Shuster, W.D., et al., Impediments and Solutions to Sustainable, Watershed-scale Urban Stormwater Management: Lesson from Australian and the United States, Environmental Management, 42, 2008, pp. 344359.

5. Miguez, M.G., Veról, A.P., and Carneiro, P.R.F., Sustainable Drainage Systems: An Integrated Approach, Combining Hydraulic Engineering Design, Urban Land Control and River Revitalisation Aspects, Drainage Systems, Javaid, M.S., Ed., InTech: Rijeka, Croatia, 2012.

6. Charlesworth, S.M., A Review of the Adaptation and Mitigation of Global Climate Change Using Sustainable Drainage in Cities, Journal of Water and Climate Change, 1, 2010, pp. 165-180.

7. Kusumastuti, C., Djajadi, R., Winarko, E.A., \& Richard, E.A., Dampak Perubahan Tata Guna Lahan terhadap Besarnya Debit banjir di Kabupaten Probolinggo, Paper presented to $35^{\text {th }}$ Scientific Annual Meeting (Pertemuan Ilmiah Tahunan) of Indonesian Hydraulics Engineers, Medan, Indonesia, 2018.

8. Ministry of Public Works of Indonesia, Ministerial Regulation No. 12/PRT/M/2014, Ministry of Public Works of Indonesia, Jakarta, 2014.

9. Ardiyana, M., Bisri, M., and Sumiadi, Studi Penerapan Ecodrain pada Sistem Drainase Perkotaan, Jurnal Teknik Pengairan, 7(2), 2016, pp. 295-300.

10. Aflakhi A., Cahyani, V.B., Kurniani, D., and Budieny, H., Perencanaan Eko-drainase Kawasan Perumahan Tembalang Pesona Asri-Semarang, Jurnal Karya Teknik Sipil, 3(2), 2014, pp. 436- 442.

11. Statistics of Mojokerto City, Mojokerto Municipality in Figures, Statistics of Mojokerto City, Mojokerto, 2017.

12. Climate-data.org, Tabel Iklim Mojokerto, retrieved from: http://id.climate-data.org/location/97 7152/, 2016. 
13. World Health Organization, Technical Notes on Drinking-Water, Sanitation and Hygiene in Emergencies, Water, Sanitation, Hygiene and Health Unit, Geneva, 2013.

14. Chow, V.T., Maidment, D.R., and Mays, L.W., Applied Hydrology, Mc.Graw-Hill, United State of America, 1988.

15. Triatmodjo, B., Hidrologi Terapan, Beta Offset, Yogyakarta, 2009.

16. Indonesian Government, Law of Republic of Indonesia No. 26, Government of Indonesia, Jakarta, 2007.
17. Wibisono, K. and Hartono, A.C., Undergraduate Thesis (Skripsi No: 21012136/SIP/2016; 150121 36/SIP/2016: Penerapan Sistem Ekodrainase pada Perumahan X di Mojokerto dan Estimasi Biayanya), Petra Christian University, Surabaya, 2016.

18. Worm, J. and Hattum, Rainwater Harvesting for Domestic Use, Agromisa Foundation and CTA, Wageningen, 2006. 